\title{
Anti-corrosion protection of aluminium alloy by zeolite doped with zinc, calcium and manganese cations
}

\author{
I.M. Zin, (i) S.A. Korniy, M.-O.M. Danyliak, O.P. Khlopyk \\ and M.Ya. Holovchuk \\ Karpenko Physico-Mechanical Institute of National Academy of Science of Ukraine, \\ Naukova str., 5, 79060, Lviv, Ukraine \\ *E-mail: ivanzin2050@gmail.com
}

\begin{abstract}
Ecologically safe anti-corrosion pigments based on synthetic zeolite Na-A modified with zinc, calcium and manganese were synthesized using liquid-phase ion exchange. The dispersion of the modified zeolites, their initial chemical composition and changes upon exposure to $0.1 \%$ sodium chloride solution were studied by scanning electron microscopy (SEM) and energydispersive X-ray microanalysis (EDX). The corrosion resistance of aluminum alloy D16T in $0.1 \% \mathrm{NaCl}$ solution and in inhibited solutions containing modified zeolites was studied using the methods of potentiodynamic polarization and electrochemical impedance spectroscopy (EIS). It was revealed that the use of modified zeolites increases the corrosion resistance of aluminum alloy in the corrosive solution by 2-9 times depending on their concentration and type of metal cation. Electrochemical impedance spectroscopy showed that the presence of modified Zn-zeolite at a concentration of $2 \mathrm{~g} / \mathrm{l}$ in the corrosive solution increases the charge transfer resistance of the sample of aluminum alloy by about 5 times. The greatest anti-corrosion effect on the aluminum alloy is provided by the zeolite modified with $\mathrm{Zn}^{2+}$, while the smallest, by the zeolite modified with $\mathrm{Ca}^{2+}$, due to the different ability of these divalent cations to desorb from the zeolite into the corrosive environment. It was found that the anticorrosive effect on the aluminum alloy D16T in an inhibited solution with $\mathrm{Zn}$-zeolite is due to the formation of continuous oxide-hydroxide layers in the vicinity of intermetallic inclusions on its surface. The chemical analysis of modified zeolites after $96 \mathrm{~h}$ of exposure to aluminum alloy D16T in solutions with a concentration of $2 \mathrm{~g} / \mathrm{l}$ confirms the preservation of the aluminosilicate skeleton of zeolite and indicates slow ion exchange of divalent cations of calcium, zinc and manganese for sodium cations from corrosion solution. The obtained modified zeolites have the potential to be used for the development of "smart coating" technologies for corrosion protection of aluminum alloys.
\end{abstract}

Received: November 22, 2021. Published: December 9, 2021

doi: $\underline{10.17675 / 2305-6894-2021-10-4-22}$

Keywords: zeolite, divalent metals cations, corrosion, aluminum alloy, liquid-phase ion exchange, inhibiting pigments SEM, EIS, EDX. 


\section{Introduction}

Aluminum alloys are commonly used as structural materials in various industries due to their high strength and low density [1]. They contain various alloying elements, such as copper, manganese, iron, silicon, magnesium, zinc, which interact in the matrix of the alloy to form particles of the secondary phase (intermetallics). The intermetallic phase provides the aluminum alloy with high strength, but also increases its susceptibility to local electrochemical corrosion. The cathode process mainly takes place on intermetallic inclusions with a higher electrochemical potential, while the anodic reaction occurs on the aluminum matrix of the alloy [2,3]. The film of alumina cannot effectively cover the inclusion of the intermetallic phase of the aluminum alloy, and therefore electrochemical reactions are facilitated in their vicinity. Effective protection against corrosion of aluminum alloys in corrosive environments can be provided by corrosion inhibitors and paints with anti-corrosion pigments [4-8], which are subjected to increasing requirements for environmental safety and rapid disposal.

Environmentally safe substances based on plant raw materials or natural minerals are becoming promising candidates for the synthesis of new corrosion inhibitors [9-13]. An important direction for the development of new technologies for corrosion protection of aluminum alloys is the use of paints with inhibiting pigments, which are environmentally friendly, have high efficiency, and can replace chromates [14-16]. Such substances include aluminosilicate minerals, in particular zeolites [17], the ion-exchange properties of which can be used to create "smart coatings" [18]. Nanoscale zeolite pores are natural nanocontainers for the intercalation of inhibitors, in particular anti-corrosion metal cations or phosphates, which can increase their effectiveness in preventing underfilm corrosion [19-22].

Therefore, the aim of this work was to study the possibility of reducing corrosion of aluminum alloy using synthetic zeolite type Na-A, modified with calcium, zinc, and manganese cations, which in the future could act as an inhibiting pigment of the "nanocontainer" type in paint coatings on aluminum alloys.

\section{Experimental}

The Na-A zeolite $\left(\mathrm{Na}_{2} \mathrm{O} \cdot \mathrm{Al}_{2} \mathrm{O}_{3} \cdot 2 \mathrm{SiO}_{2} \cdot \mathrm{H}_{2} \mathrm{O}\right)$ was used in this work. It is characterized by high porosity and sorption capacity and large sizes entrances into structural cavities $(0.42-0.44 \mathrm{~nm})$, which emphasizes the priority of the zeolite for modification with anticorrosion cations. Zeolite was ground on a Retsch PM 100 planetary ball mill before ion exchange, resulting in a powder with a dispersion of about $1-3 \mu \mathrm{m}$. According to the results of EDX (Figure 1, Table 1), the chemical composition of the obtained powder corresponds to the one stated by the zeolite manufacturer.

The obtained dispersed zeolite powder was modified by the liquid-phase ion exchange method using $0.45 \mathrm{M}$ solutions of $\mathrm{Ca}\left(\mathrm{NO}_{3}\right)_{2} \cdot 4 \mathrm{H}_{2} \mathrm{O}, \mathrm{Zn}\left(\mathrm{NO}_{3}\right)_{2} \cdot 6 \mathrm{H}_{2} \mathrm{O}$ and $\mathrm{Mn}\left(\mathrm{NO}_{3}\right)_{2} \cdot 6 \mathrm{H}_{2} \mathrm{O}$ at $70^{\circ} \mathrm{C}$ under static conditions. 

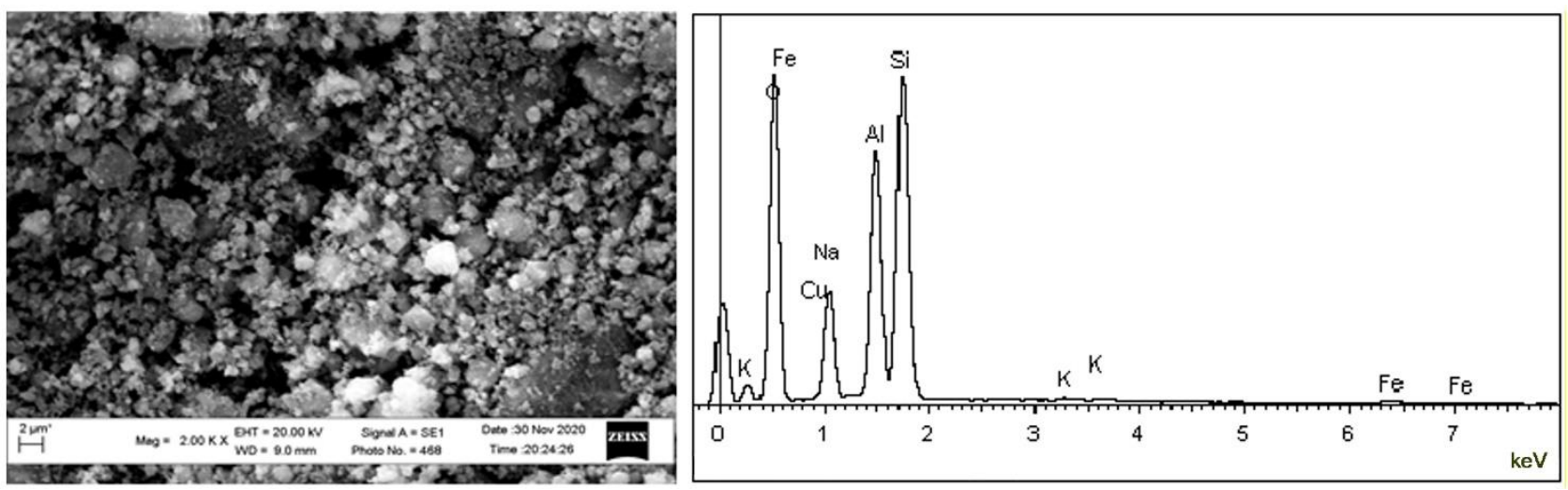

Figure 1. Chemical composition of the zeolite $\mathrm{Na}-\mathrm{A}$ according to the EDX measurements.

Table 1. The chemical composition of the zeolite, wt.\%.

\begin{tabular}{ccccccc}
\hline $\mathbf{O}$ & $\mathbf{S i}$ & $\mathbf{A l}$ & $\mathbf{N a}$ & $\mathbf{F e}$ & $\mathbf{C u}$ & $\mathbf{K}$ \\
\hline 54.10 & 20.98 & 14.06 & 9.71 & 0.65 & 0.30 & 0.19 \\
\hline
\end{tabular}

The corrosion resistance of D16T aluminum alloy was investigated by potentiodynamic polarization in $0.1 \% \mathrm{NaCl}$ solution with the addition of ion-modified zeolite using MTech COR-500 potentiostat, saturated $\mathrm{Ag} / \mathrm{AgCl}$ reference electrode and auxiliary platinum electrode. The potential scan rate during the experiments was $2 \mathrm{mV} / \mathrm{s}$. Characteristics of corrosion inhibition of aluminum alloy by ion-modified zeolite were investigated by EIS. The major advantage of the EIS method over others is the lack of destructive effects on a test sample. In addition, this method makes it possible to study protective films on metals with high barrier characteristics. To perform measurements, a three-electrode cell was used, consisting of a silver chloride reference, a platinum auxiliary and a working electrodes. Impedance measurements were performed at free corrosion potential using a Gill AC potentiostat in the AC frequency range of $1000-0.01 \mathrm{~Hz}$. The amplitude of the applied AC signal was $10 \mathrm{mV}$. The working area of the aluminum alloy samples was $1 \mathrm{~cm}^{2}$.

Surface morphology and elemental composition of aluminum alloy D16T and modified zeolites after exposure in the studied solutions were elucidated on a scanning electron microscope ZEISS EVO-40XVP with X-ray energy dispersion microanalysis system INCA Energy 350.

\section{Results and Discussion}

The polarization curves of the aluminum alloy D16T after $24 \mathrm{~h}$ of exposure to $0.1 \% \mathrm{NaCl}$ solution without and with modified zeolites are shown in Figure 2. Corrosion potentials $\left(E_{\text {cor }}\right)$ and corrosion current densities were calculated from the curves and are shown in Table 2. Electrochemical corrosion of the aluminum alloy in sodium chloride solution with a concentration of modified zeolites $1 \mathrm{~g} / \mathrm{l}$ occurs under mixed control. The greatest anticorrosion effect on the aluminum alloy is caused by zeolite modified with zinc cations, the 
smallest - modified with calcium cations. This is most likely due to the different ability of these divalent cations to desorb from zeolite into the corrosive media. It was previously shown [23] that the sorption and desorption properties of calcium, zinc and manganese ions with regard to ion-modified $\mathrm{Na}$-A type zeolites increase in the order of $\mathrm{Ca}^{2+}<\mathrm{Mn}^{2+}<\mathrm{Zn}^{2+}$, which is probably due to their electronic structure, in particular the ion radius.
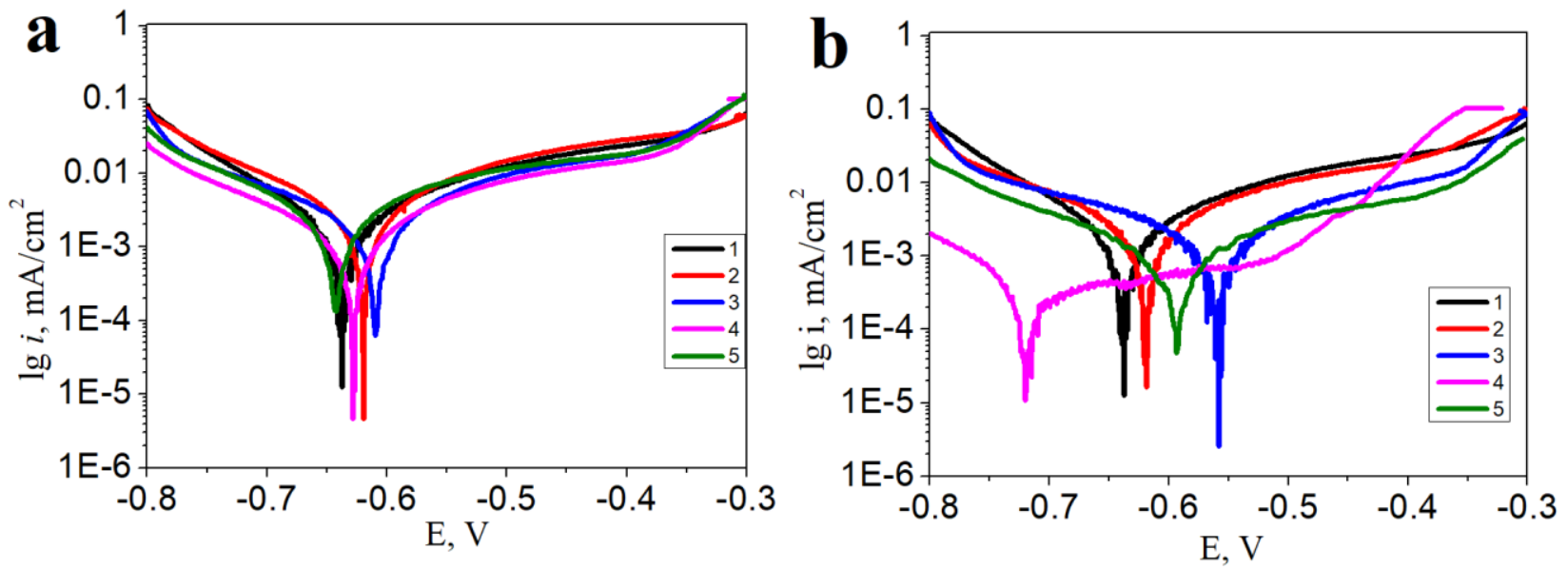

Figure 2. Polarization curves of aluminum alloy D16T after 24 hours of exposure to: $1-0.1 \% \mathrm{NaCl}$ solution and to solutions with modified zeolites with a concentration of $1 \mathrm{~g} / \mathrm{l}$ (a) and $2 \mathrm{~g} / \mathrm{l}$ (b): 2 - unmodified zeolite; 3 - Ca-zeolite; 4 - Zn-zeolite; 5 - Mn-zeolite.

Table 2. Electrochemical characteristics of aluminum alloy D16T after exposure to $0.1 \% \mathrm{NaCl}$ solution without and with ion-modified zeolites.

\begin{tabular}{|c|c|c|c|c|}
\hline \multirow{2}{*}{$\begin{array}{c}\text { Exposition } \\
\text { Characteristic }\end{array}$} & \multicolumn{2}{|c|}{24 hours } & \multicolumn{2}{|c|}{96 hours } \\
\hline & $E_{\text {cor, }}, \mathbf{V}$ & $i_{\mathrm{cor}}, \mathrm{mA} / \mathrm{cm}^{2}$ & $E_{\text {cor, }}, \mathbf{V}$ & $i_{\mathrm{cor}}, \mathbf{m A} / \mathrm{cm}^{2}$ \\
\hline Zeolite concentration & \multicolumn{4}{|c|}{$1 \mathrm{~g} / \mathrm{l}$} \\
\hline $0.1 \% \mathrm{NaCl}$ solution & -0.64 & 0.0018 & -0.61 & 0.0015 \\
\hline $0.1 \% \mathrm{NaCl}$ solution + unmodified zeolite & -0.62 & 0.0016 & -0.56 & 0.0016 \\
\hline $0.1 \% \mathrm{NaCl}$ solution $+\mathrm{Ca}^{2+}$-zeolite & -0.61 & 0.0014 & -0.56 & 0.0014 \\
\hline $0.1 \% \mathrm{NaCl}$ solution $+\mathrm{Zn}^{2+}$-zeolite & -0.63 & 0.0010 & -0.67 & 0.0004 \\
\hline $0.1 \% \mathrm{NaCl}$ solution $+\mathrm{Mn}^{2+}$-zeolite & -0.64 & 0.0016 & -0.69 & 0.0008 \\
\hline Zeolite concentration & \multicolumn{4}{|c|}{$2 \mathrm{~g} / \mathrm{l}$} \\
\hline $0.1 \% \mathrm{NaCl}$ solution + unmodified zeolite & -0.62 & 0.0018 & -0.61 & 0.0015 \\
\hline $0.1 \% \mathrm{NaCl}$ solution $+\mathrm{Ca}^{2+}$-zeolite & -0.56 & 0.0008 & -0.54 & 0.0016 \\
\hline $0.1 \% \mathrm{NaCl}$ solution $+\mathrm{Zn}^{2+}$-zeolite & -0.72 & 0.0002 & -0.64 & 0.0001 \\
\hline $0.1 \% \mathrm{NaCl}$ solution $+\mathrm{Mn}^{2+}$-zeolite & -0.59 & 0.0005 & -0.64 & 0.0005 \\
\hline
\end{tabular}


Increase of modified zeolites concentration in the chloride solution to $2 \mathrm{~g} / \mathrm{l}$ enhances corrosion resistance of the aluminum alloy. In zeolite extracts, the corrosion current density of the metal decreases by 2-9 times, as compared to the uninhibited solution (Table 2). Apparently, it is due to the fact that $\mathrm{Ca}^{2+}, \mathrm{Mn}^{2+}$ and $\mathrm{Zn}^{2+}$ cations, adsorbed on the surface of the alloy, form a protective film, which prevents the diffusion of oxygen molecules and $\mathrm{Cl}^{-}$ions thus reducing the rate of electrochemical reactions.

The most pronounced protective effect of the studied modified zeolites is observed after 96-hour alloy exposure to the solution with modified $\mathrm{Mn}$ - and $\mathrm{Zn}$-zeolites, which can be explained by the formation of dense sparingly soluble zinc and manganese hydroxides. Meanwhile, the greatest anti-corrosion effect is shown by the zeolite modified by zinc cations (Figure 3).
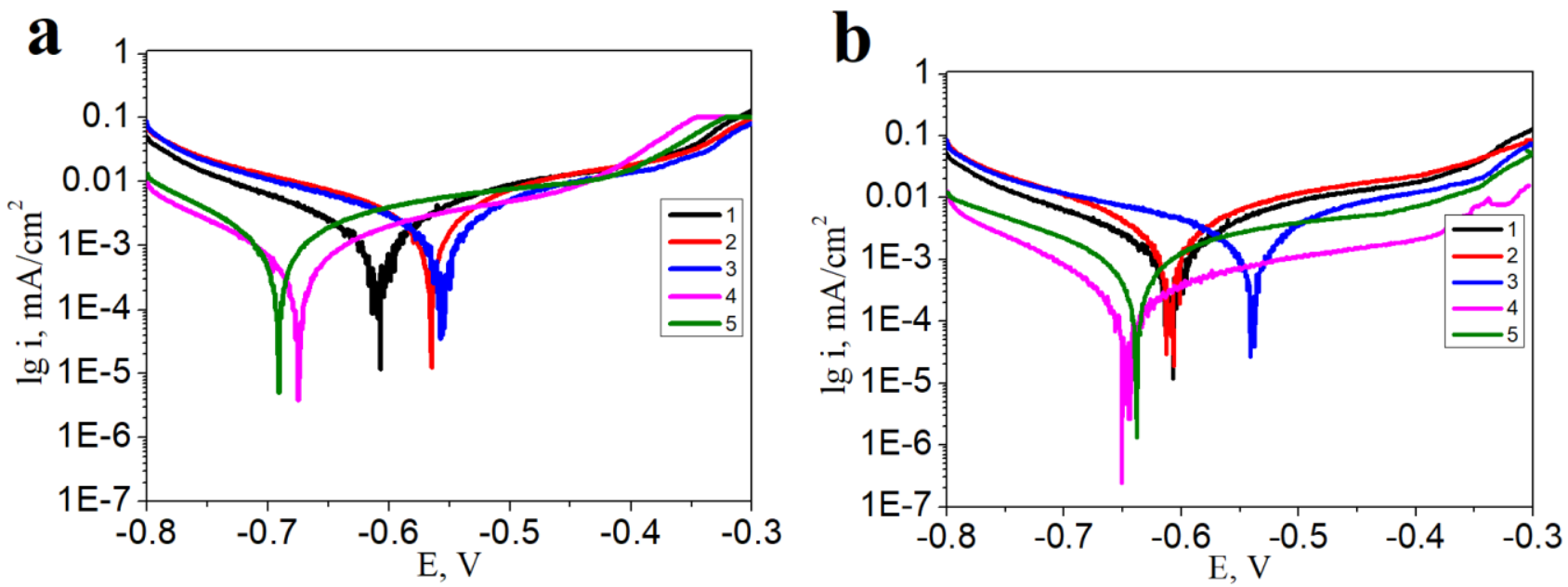

Figure 3. Polarization curves of aluminum alloy D16T after 96 hours of exposure to:

$1-0.1 \% \mathrm{NaCl}$ solution and to the solutions with modified zeolites with a concentration of $1 \mathrm{~g} / \mathrm{l}$ (a) and $2 \mathrm{~g} / \mathrm{l}$ (b): 2 - unmodified zeolite; 3 - Ca-zeolite; 4 - Zn-zeolite;

5 - Mn-zeolite.

The next step was to investigate the inhibition efficiency of ion-modified zeolites in chloride solution by EIS. Impedance spectra of D16T alloy samples were taken after 24 and $48 \mathrm{~h}$ of exposure to the test solutions. Measurements were performed at the corrosion potential. Resulting diagrams are presented in the form of Bode dependencies (Figure 4). It was found that the impedance modulus of the alloy in Zn-zeolite-inhibited solution at a frequency of $0.1 \mathrm{~Hz}$ is 2 times higher, as compared to $\mathrm{Mn}$-zeolite, and approximately 5 times higher as for the alloy in the solution inhibited by Ca-zeolite. These data are consistent with the results of electrochemical polarization studies and indicate the formation of a sparingly soluble hydroxide film on the cathode sections of the aluminum alloy involving zinc ions desorbed from the zeolite during ion exchange. 

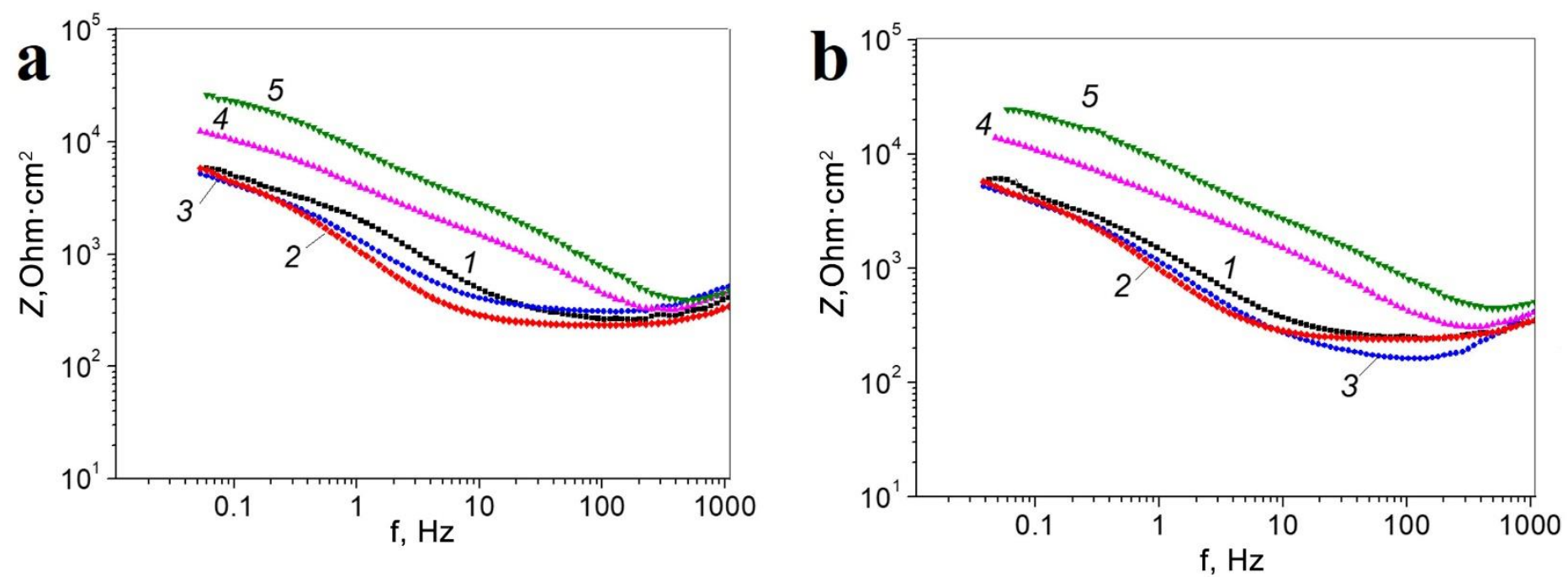

Figure 4. Dependencies of the D16T alloy impedance modulus after 24 (a) and 48 (b) hours of exposure to $0.1 \% \mathrm{NaCl}$ solution without (1) and with zeolites at a concentration of $2 \mathrm{~g} / \mathrm{l}$ : 2 - unmodified zeolite; 3 - Ca-zeolite; 4 - Mn-zeolite ; 5 - Zn-zeolite.

It should be noted that adding of zeolite, modified with zinc and manganese cations, to the corrosive medium shifts the maximum of the phase angle towards higher AC frequencies (Figure 5). This is usually due to the formation of a barrier film with increased protective properties on the surface of the alloy [24]. The shift of the phase angle maximum towards the lower AC frequencies for samples of aluminum alloy in solutions inhibited by unmodified zeolite and Ca-zeolite may be a consequence of the formation of pitting on the surface of the metal.
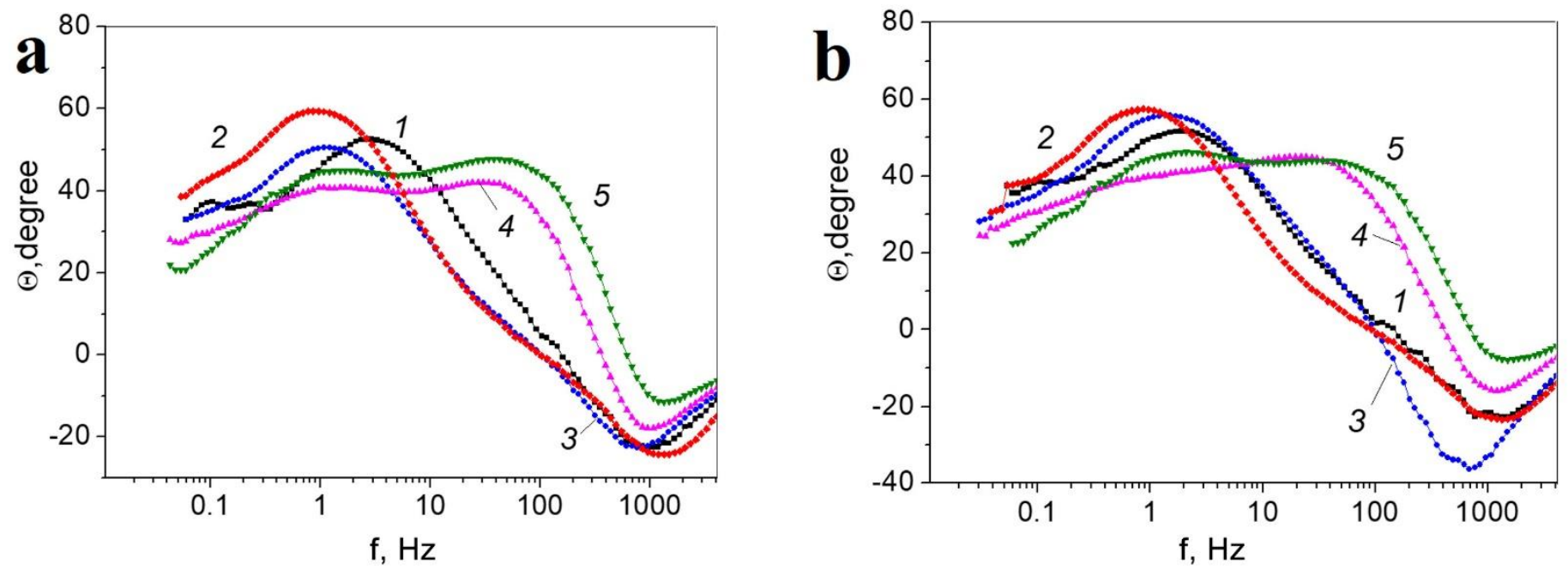

Figure 5. Dependencies of the phase angle for D16T alloy after 24 (a) and 48 (b) hours of exposure to: $1-0.1 \% \mathrm{NaCl}$ solution without (1) and with zeolites at a concentration of $2 \mathrm{~g} / \mathrm{l}$ : 2 - unmodified zeolite; 3 - Ca-zeolite; 4 - Mn-zeolite ; 5 - Zn-zeolite. 
To model the impedance spectra with EIS Spectrum Analyzer program, the equivalent electrical circuit consisting of resistance elements $\left(R_{\mathrm{s}}-\right.$ electrolyte resistance; $R_{\mathrm{ct}}-$ charge transfer resistance) and a constant phase element $(Q)$, which replaces a double layer capacitance, was used (Figure 6). Replacing the usual capacitance of the electric double layer with $Q$ in the equivalent circuit model made it possible to calculate the parameters of impedance dependencies with minimal error [25].

The impedance of the constant phase element can be expressed as:

$$
Z_{Q}=\frac{1}{\left[Y_{0}(j \omega)^{n}\right]}
$$

where $Y_{0}$ is the frequency independent admittance of $Q, s^{n} / \mathrm{Ohms} \cdot \mathrm{cm}^{2} ; \omega$ is the angular frequency, $1 / \mathrm{s} ; n$ is the empirical exponent of $Q$ that always lies between -1 and 1 . Depending on the value of exponent $n$, the physical meaning of $Q$ can be related to pure capacitance $(n=1)$, Warburg impedance $(n=0.5)$, pure resistor $(n=0)$ and pure inductance $(n=-1)$.

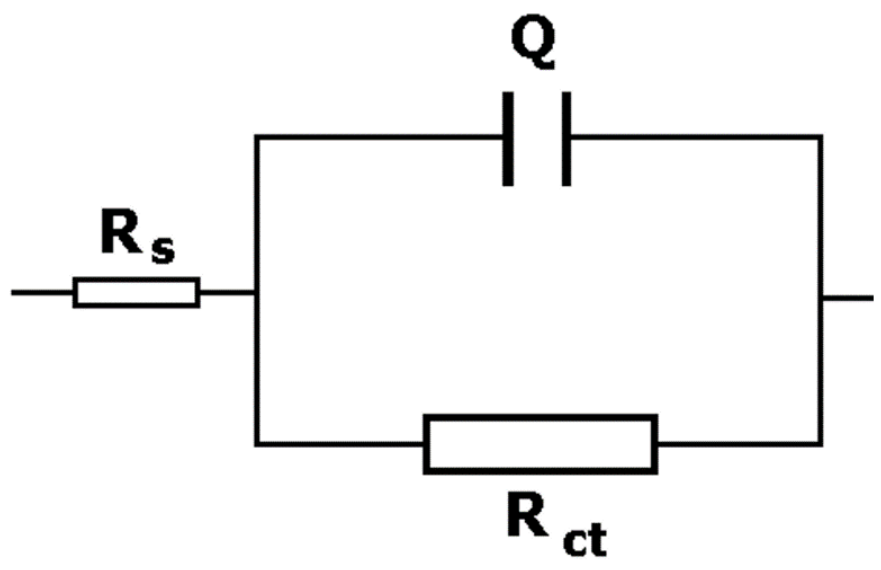

Figure 6. Equivalent circuit for EIS spectra modelling.

It was found that the presence of modified Zn-zeolite at a concentration of $2 \mathrm{~g} / \mathrm{l}$ in the corrosive solution increases the charge transfer resistance of the sample of aluminum alloy by about 5 times (Table 3). At the same time, the component of the constant phase element $Y_{0}$ for the aluminum alloy in this solution is reduced by an order of magnitude. In the inhibited solution, this component is strongly influenced by diffusion restrictions, as evidenced by the decrease in the value of $n$ to 0.59 . These constraints of the corrosion reaction can be caused by the formation of a protective film in the pores of the oxide layer. For the alloy sample in the solution with $2 \mathrm{~g} / \mathrm{l}$ of modified Mn-zeolite, 3-fold increase of the transfer resistance was observed, which indicates slightly less inhibition of metal corrosion.

When using unmodified zeolite and Ca-zeolite, $R_{\mathrm{ct}}$ values of the alloy were the lowest, which indicates unsatisfactory protection of the metal and flow of corrosion process. 
Table 3. Characteristics of equivalent circuit (Figure 5) derived from modelling of EIS spectra of D16T alloy samples

\begin{tabular}{|c|c|c|c|c|c|c|}
\hline \multirow{2}{*}{ Solution } & \multicolumn{2}{|c|}{$R_{\mathrm{ct}}, \mathrm{Ohm} \cdot \mathrm{cm}^{2}$} & \multicolumn{2}{|c|}{$Q\left(Y_{0}\right), s^{n} / \mathrm{Ohm} \cdot \mathrm{cm}^{2}$} & \multicolumn{2}{|c|}{$Q(n)$} \\
\hline & 24 hours & 48 hours & 24 hours & 48 hours & 24 hours & 48 hours \\
\hline $0.1 \% \mathrm{NaCl}$ solution & 7436 & 7497 & $1.3 \cdot 10^{-4}$ & $1.8 \cdot 10^{-4}$ & 0.735 & 0.76 \\
\hline $\begin{array}{c}1 \% \mathrm{NaCl}+2 \mathrm{~g} / \mathrm{l} \text { unmodified } \\
\text { zeolite }\end{array}$ & 4842 & 6549 & $1.5 \cdot 10^{-4}$ & $2.4 \cdot 10^{-4}$ & 0.79 & 0.83 \\
\hline $0.1 \% \mathrm{NaCl}+2 \mathrm{~g} / 1 \mathrm{Ca}^{2+}$-zeolite & 6782 & 6164 & $2.0 \cdot 10^{-4}$ & $2.2 \cdot 10^{-4}$ & 0.76 & 0.77 \\
\hline $0.1 \% \mathrm{NaCl}+2 \mathrm{~g} / 1 \mathrm{Mn}^{2+}$-zeolite & 22185 & 21852 & $7.8 \cdot 10^{-5}$ & $7.2 \cdot 10^{-5}$ & 0.55 & 0.58 \\
\hline $0.1 \% \mathrm{NaCl}+2 \mathrm{~g} / 1 \mathrm{Zn}^{2+}$-zeolite & 39978 & 38491 & $3.2 \cdot 10^{-5}$ & $2.2 \cdot 10^{-4}$ & 0.59 & 0.60 \\
\hline
\end{tabular}

After 96 hours of sample exposure to corrosion solution containing modified zeolites, the surface of the D16T aluminum alloy was examined by SEM and the chemical composition of different parts (1 and 2) of the alloy surface was determined using EDX (Figure 7, Table 4). It should be noted that the elemental composition of the formed products on the aluminum matrix of the alloy (1) differs from the composition of the surface film on intermetallic inclusions (2). The results of the analysis show that after exposure of the alloy to the extracts of modified zeolites, the concentration of calcium, manganese and zinc is higher in areas 2, which correspond to intermetallic inclusions. Thus, calcium, manganese and zinc cations desorbed into a solution from modified zeolites are directly deposited in the areas of intermetallic inclusions, which are known to be the cathode regions of the aluminum alloy. Significant zinc content was detected in section 2 and almost complete absence of components of intermetallic inclusions (copper, magnesium and manganese) was seen on the energy dispersion spectrum, which indicates the formation of a continuous film of zinc hydroxide, complete blocking of cathode sections of the alloy and deceleration of corrosion processes. Upon alloy exposure to the solution with modified Ca-zeolite, non-dense products and increased content of copper and manganese are observed on its surface, which indicates direct contact of the corrosion solution with the cathodic inclusions. On the other hand, some products containing manganese, possibly as manganese hydroxides, are observed on the alloy surface in the vicinity of cathodic inclusions after exposure to the solution containing Mn-zeolite. They do not completely cover the intermetallics surface, but partially block the cathodic reactions. These data may explain the results of electrochemical spectroscopy regarding corrosion resistance of aluminum alloy in extracts containing zeolites modified with manganese. 

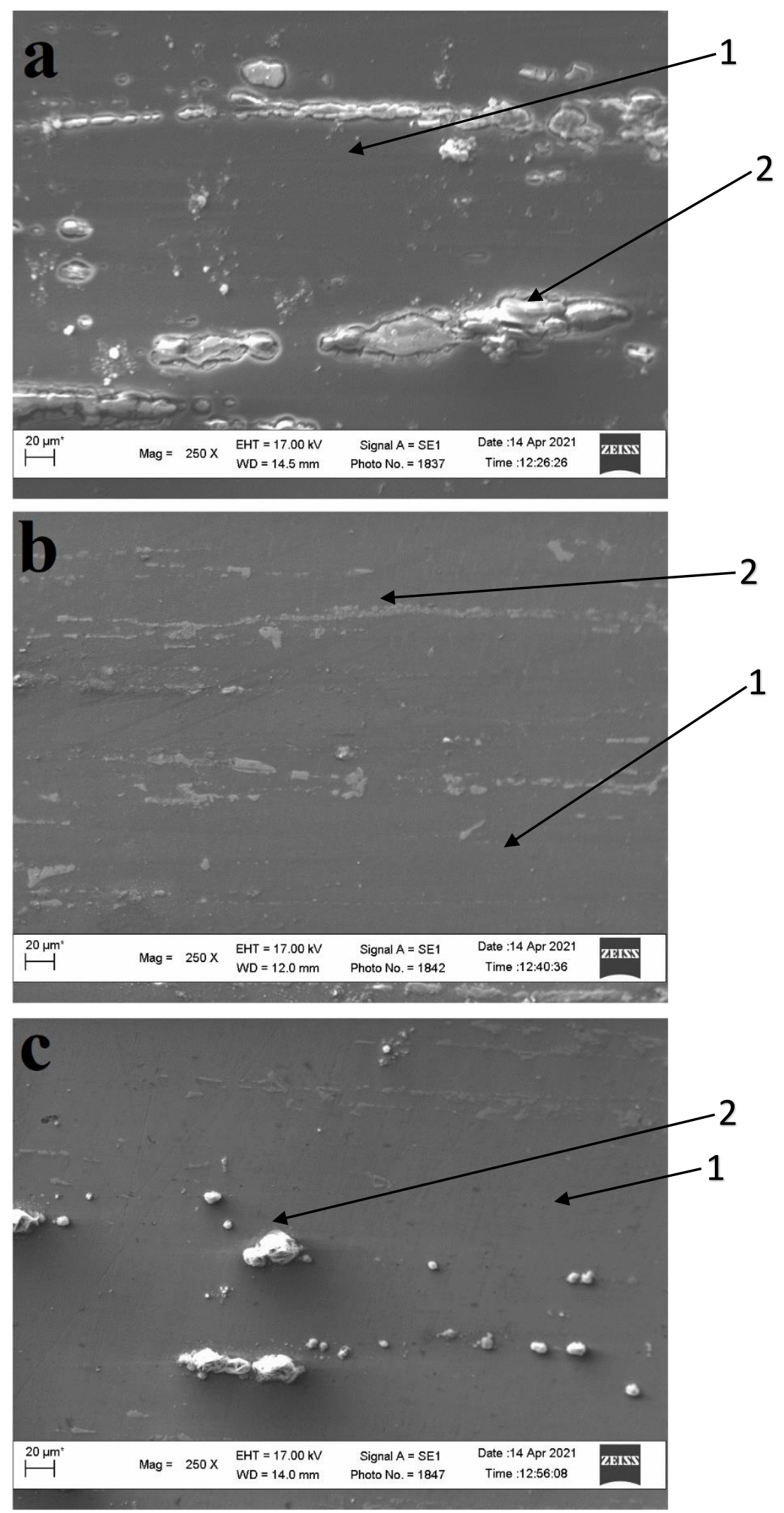

Figure 7. SEM images of the surface of the aluminum alloy D16T after 96 hours of exposure to solutions with modified zeolites at a concentration of $2 \mathrm{~g} / \mathrm{l}: \mathrm{a}-\mathrm{Ca}-\mathrm{zeolite} ; \mathrm{b}-\mathrm{Zn}$-zeolite; c-Mn-zeolite . 1 - aluminum matrix of the alloy; 2 - intermetallic inclusions. 
Table 4. Chemical composition (in wt.\%) of the surface of the aluminum alloy D16T after 96 hours exposure to solutions with modified zeolites at a concentration of $2 \mathrm{~g} / \mathrm{l}$ in areas 1 and 2 (see Figure 5).

\begin{tabular}{|c|c|c|c|c|c|c|}
\hline \multirow{4}{*}{ Element } & \multicolumn{6}{|c|}{ Type of modified zeolite } \\
\hline & \multicolumn{2}{|c|}{ Ca-zeolite } & \multicolumn{2}{|c|}{ Zn-zeolite } & \multicolumn{2}{|c|}{ Mn-zeolite } \\
\hline & \multicolumn{6}{|c|}{ Surface area } \\
\hline & 1 & 2 & 1 & 2 & 1 & 2 \\
\hline $\mathrm{O}$ & 29.82 & 33.92 & 1.57 & 43.41 & 9.58 & 3.75 \\
\hline $\mathrm{Mg}$ & 1.21 & - & 1.49 & - & 1.32 & - \\
\hline $\mathrm{Al}$ & 63.55 & 12.60 & 92.64 & 11.13 & 85.26 & 67.78 \\
\hline $\mathrm{Si}$ & 1.37 & 3.66 & - & - & - & 3.91 \\
\hline $\mathrm{Mn}$ & 0.50 & 6.74 & 0.71 & - & 0.67 & 6.05 \\
\hline $\mathrm{Cu}$ & 3.27 & 33.24 & 3.58 & 0.58 & 3.16 & 7.30 \\
\hline $\mathrm{Fe}$ & - & 7.43 & - & - & - & 11.19 \\
\hline $\mathrm{Ca}$ & 0.29 & 2.41 & - & - & - & - \\
\hline $\mathrm{Na}$ & - & - & - & 7.21 & - & - \\
\hline $\mathrm{Zn}$ & - & - & - & 37.66 & - & - \\
\hline
\end{tabular}

With regard to the long-term inhibitory action, an important property of modified zeolites as anti-corrosion pigments is the stability of the aluminosilicate framework in a corrosion environment and the slow release of their cations. To assess this property, modified zeolites obtained after drying of the respective inhibited solutions, in which electrochemical investigations of the aluminum alloy were performed, were studied by EDX analysis. EDX of modified zeolites, dried after 96 hours of exposure to corrosion solutions at a concentration of $2 \mathrm{~g} / \mathrm{l}$ and with immersed samples of D16T alloy, confirms the preservation of the aluminosilicate framework and shows a slow exchange of calcium, zinc and manganese cations to $\mathrm{Na}^{+}$ions (Table 5).

The ratio of $\mathrm{Si} / \mathrm{Al}$ in the aluminosilicate skeleton of zeolites exposed to the corrosion solution practically did not change and is equal to $1.31,1.44$ and 1.47 for $\mathrm{Ca}-\mathrm{Mn}$ - and $\mathrm{Zn}$ containing zeolitic pigments, respectively. This finding indicates stability of the aluminosilicate skeleton of the zeolite and confirms the occurrence of ion-exchange reactions with exchangeable non-frame ions on the skeleton. 
Table 5. The chemical composition (wt.\%) of the original modified zeolites (1) and obtained by drying the corresponding inhibited solutions containing $2 \mathrm{~g} / \mathrm{l}$ of these aluminosilicates after 96 hours of aluminum alloy exposure (2).

\begin{tabular}{ccccccc}
\hline & \multicolumn{7}{c}{ Type of modified zeolite } \\
\cline { 2 - 7 } Element & \multicolumn{2}{c}{ Ca-zeolite } & \multicolumn{2}{c}{ Zn-zeolite } & \multicolumn{2}{c}{ Mn-zeolite } \\
\cline { 2 - 7 } & $\mathbf{1}$ & $\mathbf{2}$ & $\mathbf{1}$ & $\mathbf{2}$ & $\mathbf{1}$ & $\mathbf{2}$ \\
\hline $\mathrm{O}$ & 53.01 & 53.96 & 47.67 & 48.39 & 49.13 & 53.18 \\
$\mathrm{Na}$ & 3.07 & 3.26 & 4.17 & 4.28 & 2.46 & 3.46 \\
$\mathrm{Al}$ & 14.55 & 15.34 & 12.49 & 13.38 & 10.65 & 13.96 \\
$\mathrm{Si}$ & 19.06 & 20.12 & 18.23 & 19.72 & 14.97 & 20.17 \\
$\mathrm{Ca}$ & 6.15 & 5.86 & - & 0.67 & 0.12 & 0.9 \\
$\mathrm{Mn}$ & - & - & - & - & 7.66 & 7.26 \\
$\mathrm{Fe}$ & 0.51 & 0.57 & 0.51 & 0.71 & 0.48 & 0.59 \\
$\mathrm{Zn}$ & - & - & 14.38 & 12.85 & - & - \\
$\mathrm{C}$ & 3.65 & - & 4.67 & - & 14.38 & - \\
$\mathrm{K}$ & - & 0.23 & - & - & 0.14 & - \\
$\mathrm{Cu}$ & - & - & - & - & - & 0.47 \\
\hline
\end{tabular}

\section{Conclusions}

It was found that zeolite $\mathrm{Na}-\mathrm{A}$, modified with calcium, zinc and manganese by liquid-phase ion exchange, inhibits the corrosion of aluminum alloy in a neutral environment of $0.1 \%$ $\mathrm{NaCl}$ and its protective efficiency depends on the type of metal cation. Electrochemical studies showed that the corrosion current density of the aluminum alloy decreases by 2-9 times in solutions with modified zeolites, as compared to the uninhibited solution.

The presence of $\mathrm{Zn}$-zeolite at a concentration of $2 \mathrm{~g} / \mathrm{l}$ in the corrosive solution increases the resistance to charge transfer of the aluminum alloy by about 5 times. At the same time, the value of the component $Y_{0}$ of the constant phase element for the aluminum alloy in this solution decreases by an order of magnitude. A 3-fold increase in the charge transfer resistance was observed for the alloy sample in the solution with modified Mn-zeolite, indicating slightly less inhibition of metal corrosion. The $R_{\mathrm{ct}}$ resistance values for the alloy were the lowest when using unmodified zeolite and Ca-zeolite, which points out insufficient protection of the alloy. The addition of zeolite modified with zinc and manganese cations to the corrosion solution shifts the maximum phase angle towards higher AC frequencies, which indicates the formation of a barrier film with increased protective properties on the surface of the alloy. 
The inhibitory effect of the modified zeolites is due to the formation of insoluble oxidehydroxide layers or individual islands in the vicinity of intermetallic inclusions of aluminum alloy and it increases in the order of Ca-zeolite $<$ Mn-zeolite $<$ Zn-zeolite.

SEM and EDX confirmed the occurrence of ion exchange reactions on modified zeolites in a corrosive environment and showed the stability of the structure of the aluminosilicate framework, which can contribute to the long-term corrosion protection of the aluminum alloy surface.

Based on the obtained results, ion-modified zeolites of the Na-A type can become promising inhibiting pigments in paints for the protection of aluminum alloys.

\section{Acknowledgment}

This work was performed within the project № 2020.02/0063 “Synthesis and properties of new complex anti-corrosion pigments for paint coatings based on aluminosilicate nanocontainers" of the National Research Foundation of Ukraine.

\section{References}

1. T. Kvačkaj, J. Bidulska, R. Kočiško and R. Bidulsky, Aluminium Alloys, Theory and Applications, Rijeka, InTech, 2011, 400.

2. K.A. Yasakau, M.L. Zheludkevich and M.G.S. Ferreira, Corrosion and corrosion protection of aluminum alloys, Encyclopedia of Interfacial Chemistry, 2018, 115-127. doi: $\underline{10.1016 / B 978-0-12-409547-2.13870-3}$

3. T.H. Muster, A.E. Hughes and G.E. Thompson, Copper distributions in aluminum alloys, New York, Nova Science Publishers, 2009, 116.

4. A. Kadhim, A.A. Al-Amiery, R. Alazawi, M.K.S. Al-Ghezi and R.H. Abass, Corrosion inhibitors. A review, Int. J. Corros. Scale Inhib., 2021, 10, no. 1, 54-67. doi: 10.17675/2305-6894-2021-10-1-3

5. Yu.I. Kuznetsov, Progress in the science of corrosion inhibitors, Int. J. Corros. Scale Inhib., 2015, 4, no. 1, 15-34. doi: 10.17675/2305-6894-2015-4-1-015-034

6. O.A. Goncharova, D.S. Kuznetsov, N.N. Andreev, Yu.I. Kuznetsov, N.P. Andreeva and S.S. Vesely, Corrosion screening of chamber inhibitors for an aluminum alloy, Int. J. Corros. Scale Inhib., 2019, 8, no. 2, 257-267. doi: 10.17675/2305-6894-2019-8-2-7

7. S.A Umoren, U.M Eduok, Application of carbohydrate polymers as corrosion inhibitors for metal substrates in different media: A review, Carbohydr. Polym., 2016, 140, 314-341. doi: 10.1016/j.carbpol.2015.12.038

8. S.B. Lyon, R. Bingham and D.J. Mills, Advances in corrosion protection by organic coatings: What we know and what we would like to know, Prog. Org. Coat., 2017, 102, 2-7. doi: 10.1016/j.porgcoat.2016.04.030

9. G. Palumbo, K. Berent, E. Proniewicz and J. Bana's, Guar gum as an eco-friendly corrosion inhibitor for pure aluminium in $1 \mathrm{M} \mathrm{HCl}$ solution, Materials, 2019, 12, no. 16, 2620. doi: $\underline{10.3390 / \mathrm{ma1} 162620}$ 
10. K.R. Ansari, S. Ramkumar, D.S. Chauhan, Md. Salman, D. Nalini, V. Srivastava and M.A. Quraishi, Macrocyclic compounds as green corrosion inhibitors for aluminium: electrochemical, surface and quantum chemical studies, Int. J. Corros. Scale Inhib., 2018, 7, no. 3, 443-459. doi: $10.17675 / 2305-6894-2018-7-3-13$

11. M.A. Al-Qudah, H.G. AL-Keifi, I.F. Al-Momani and S.T. Abu-Orabi, Capparis Aegyptia as a green inhibitor for aluminum corrosion in alkaline media, Int. J. Corros. Scale Inhib., 2020, 9, no. 1, 201-218. doi: 10.17675/2305-6894-2020-9-1-12

12. V. Vorobyova, O. Chygyrynets, M. Skiba, T. Zhuk, I. Kurmakova and O. Bondar, A comprehensive study of grape pomace extract and its active components as effective vapour phase corrosion inhibitor of mild steel, Int. J. Corros. Scale Inhib., 2018, 7, no. 2, 185-202. doi: 10.17675/2305-6894-2018-7-2-6

13. I.M. Zin, V.I. Pokhmurskii, S.A. Korniy, O.V. Karpenko, S.B. Lyon, O.P. Khlopyk and M.B. Tymus, Corrosion inhibition of aluminium alloy by rhamnolipid biosurfactant derived from Pseudo-monas sp. PS-17, Anti-Corros. Methods Mater., 2018, 65, no. 6, 517-527. doi: 10.1108/ACMM-03-2017-1775

14. D. Snihirova, S.V. Lamaka and M.F. Montemor, 4 - Smart composite coatings for corrosion protection of aluminium alloys in aerospace applications, Smart Composite Coatings and Membranes, 2016, 85-121. doi: 10.1016/B978-1-78242-283-9.00004-X

15. Y. Shao, C. Jia, G. Meng, T. Zhang and F. Wang, The role of a zinc phosphate pigment in the corrosion of scratched epoxy-coated steel, Corros. Sci., 2009, 51, no. 2, 371-379. doi: $10.1016 /$ j.corsci.2008.11.015

16. E. Alibakhshi, E. Ghasemi and M. Mahdavian, Sodium zinc phosphate as a corrosion inhibitive pigment. Prog. Org. Coat., 2014, 77, no. 7, 1155-1162. doi: 10.1016/j.porgcoat.2014.03.027

17. S.M. Auerbach, K.A. Carrado and P.K. Dutta, Handbook of Zeolite Science and Technology, New York-Basel, Marcel Dekker, 2003, 1170.

18. A.A. Nazeer and M. Madkour, Potential use of smart coatings for corrosion protection of metals and alloys: A review, J. Mol. Liq., 2018, 253, 11-22. doi: 10.1016/j.molliq.2018.01.027

19. N. Granizo, J.M. Vega, D. de la Fuente, J. Simancas and M. Morcillo, Ion-exchange pigments in primer paints for anticorrosive protection of steel in atmospheric service: Cation-exchange pigments, Prog. Org. Coat., 2012, 75, no. 3, 147-161. doi: 10.1016/j.porgcoat.2012.04.013

20. L. Rassouli, R. Naderi and M. Mahdavain, The role of micro/nano zeolites doped with zinc cations in the active protection of epoxy ester coating, Appl. Surf. Sci., 2017, 423, 571-583. doi: 10.1016/j.apsusc.2017.06.245

21. S.A.S. Dias, A. Marques, S.V. Lamaka, A. Simões, T.C. Diamantino and M.G.S. Ferreira, The role of Ce(III) - enriched zeolites on the corrosion protection of AA2024-T3, Electrochim. Acta, 2013, 112, 549-556. doi: 10.1016/j.electacta.2013.09.026 
22. B. Xue, X. Zong, C. Wang, H. Zhang and J. Luo, Corrosion Inhibition of a Sol-Gel Coating Modified with Cobalt Enriched Zeolite on AA2024-T3 Aluminum Alloy, Int. J. Electrochem. Sci., 2019, 14, 10966-10982. doi: 10.20964/2019.12.10

23. S.A. Korniy， I.M. Zin， O.P. Khlopyk， M.Ya. Holovchuk， M.O.M. Danyliak and S.A. Halaichak, Modification of syntetic zeolite by metal cations to increase its anticorrosion efficiency, Physicochemical Mechanics of Materials, 2021, 57, no. 1, $103-110$ (in Ukrainian).

24. L.E.M. Palomino, J.F.W. De Castro, I.V. Aoki and H.G. De Melo, Microstructural and Electrochemical Characterization of Environmentally Friendly Conversion Layers on Aluminium Alloys, J. Braz. Chem. Soc., 2003, 14, no 4, 651-659. doi: 10.1590/S0103$\underline{50532003000400024}$

25. P. Cordoba-Torres, T.J. Mesquita and R.P. Nogueira, Relationship between the origin of constant-phase element behavior in electrochemical impedance spectroscopy and electrode surface structure, J. Phys. Chem. C, 2015, 119, no. 8, 4136-4147. doi: $\underline{10.1021 / \mathrm{jp} 512063 \mathrm{f}}$ 